\title{
COMMUNICATIVE BEHAVIOR: GENDER ASPECT
}

\author{
I. Kobyakova, PhD in Philology, Professor \\ https://orcid.org/0000-0002-9505-2502 \\ Sumy State University, \\ 2, Rymskoho-Korsakova St., Sumy, 40007, Ukraine \\ E-mail: i.kobyakova@gf.sumdu.edu.ua
}

The subject matter of the article is being worded in the very title of it. The article in question focuses upon the communicative behavior of men and women in the similar situations. The gender categories are considered in the terms of emotionality and verbal behavior. The objectives, methods, aims, scholars reviews are noted herein. Emphasized are the ideas of dominant ideas of differences between male and female in communicative behavior. Language modus is of the common information of ethnic groups. The gender differences do not eliminate the right to the words and their functions. Men and women speak one language, they make one team and go together but apart. The aim of the article is to study the communication behavior (gender aspect). The peculiarities of the children upbringing follow the social traditions. Great attention is being paid to the lexicon of the people's behavior and emotionality into that. The conclusion arrived at the article is that cardinal differences work by complex biological, social, emotional behavior and psychological factors. Nowadays gender studies play the significant role in the humane and inhumane disciplines.

Key words: communicative behavior, men and female, gender aspects, emotionality, information, verbal behavior, linguo-cognitive approach.

https://doi.org/10.21272/Ftrk.2018.10(3)-08

Introduction: The relevant study of gender problem is available in the works by M. Gorodnikova, D. Dobrovolskiy, V. Zhelvis, A. Zemskaya, F. Kirylina, M.Kitaygorodska, G. Connel, G. Lansdall, D. Tannen, B. L. Worfa, I. Khaleev and others $[1,134]$. A. Hororshko deals with the problem of male and female literary speeches, peculiarities of the associative behavior and the structural-semantic designs of informative blocks [2, 100]. A.Burukina pays attention to the gender aspects of translation [3, 101]. A. Sternin shares this topic. The biological reasons aren't left either. The «two cultures» theory is termed as rapport and report. In metasign paradigm this approaches are nominated as andocentric and hipocentric, due to which men are less talkative, but more informative; the girls are talkers (lovely, small talkers) [4, 510]. Men hide their feelings, they are calm, courageous, quiet in the contrast with women, the latter are modest, timid, not courageous, not informative either.

Scientific picture of gender saga correlates with eyewitnesses the late eighties of the XX century. K. Opperman and E. Webster emphasized the gender status who look for accentuation, affinity for communicative security of the interlocutors [5, 19]. A. Linke analyzed lexicon differences of both: women think sex harmonization and minimization of differences. Men prefer independence in conversation. Women prefer diminutive, pleasing units: they look for general consensus and interaction. Men are conflict oriented, their position is always right $[6,34]$. Men conduct conversation, women let it go, establishing close relationship with parters. Topics discussions are also different with men and women. Men are fans of football, politics, nonlinear problems, business, travelling; women prefer privat affairs, small talks, domestic matters, childcare, housekeeping. Grammar differences are not great. Choice of words matters much. Women like bright words, subjunctive mood, indirect statements, evaluative adjectives, uninformative units, shy and passive style of selfexpression. Cf.: perhaps it seems to me, maybe, from my point of view, I feel, I hope, I think, I believe me thinks.

(C) I. Kobyakova, 2018

«Філологічні трактати», Том 10, № 3 ' 2018 
Gender items become proverbial with interlocutors [7, 45]. They make the heart of many picturesque paradoxes of type she lost her heart and a necklace, a devil of a woman, horribly beautiful woman, a giant of a woman, a woman of a pocketsize, a woman is at once, the serpent, the apple and bellyache; she can make at once a cake, a salad and a tragedy; she can do hair, wishes, her best, one's room and what not. Cf.: Ukr.: ide dow i студент додому, п'ю каву з сахаром та з жінкою, любив козак дівчину $i$ з сиром пироги.

Linguogenderology as a science deals with the categories of male, female and neutral taxonomy which are not formalized. Exceptions are made by units actress, heroin. Social, linguistic and cultural attributes are different with macrosystems [8, 57]. Gender criteria work wonders in the linguistic endozones. Gender comparability starts in dichotomy $\underline{\operatorname{man}}$ : woman. The priority works with man: it came to be a suffix in derivatives in positions postman, salesman, statesman, gentleman, sportsmanship, girlsmanship and showmanship.

Ethnic group of men and women are onelanguaged. The gender saga is an English phenomenon. It works idiomatic. The preference is given to andocentric tendency. The opposite tendency is that of hipocentric type (female). They compete and make a kind of philological battle. Centuries old is the idea of the andocentric type. That is vivid in correlation men :: women. The alike diversity works with synonyms. Cf.: beautiful (women), handsome (men). Semantic motivation thus works with many a synonym.

Subject matter of the topic consists in the very communicative behavior of men and women in similar situations with distinctions in the word coding. There work different professional actions with male and female [9, 21]. The dimension of their lexicon is verified by social, psychological, cognitive, cultural, linguistic and demographic modi. Men and women's speech (including communicative behavior) reflexes the gender, differences and identities. Some scientific experts assume that women act more humane, polite, emphatic and lovely in a rapport stereotype. Men act in report type - informative in their speech, position - centered, aggressive and abrupt into that. Their gender colocations are diverse in lexicon [10,32]. The word men is highly picturesque in it's epidigmatic and functional designs. This word is used for artifacts and living beings. Cf.: the man before a mast (sailor), men in the blue (policemen), men of letters (writers), many men (people "he + she"); men may meet, mountains never, all men are mental, a man of war - ship, outer man -costume, low men - legs, ironman -dollar [11].

Results of the research: Women are not so prolific, but open to semantic deviation. Cf.: the old woman is picking her geese - "it is heavily raining"; necessary woman "housekeeper"; to play the woman - "womanish man".

Proverbs work wonders with «he + she» semantic charge. Cf.:

Every man has a fool in his sleeve Нема чоловіка без вади

Every man has his hobby horse $\quad$ У кожного своя примха

Every man has his price Кожного можна купити

Every man has his weak side $\quad$ У кожного свої слабкості

Some proverbs make work for both andocentric and hipocentric tipes, grammar gender is expressed by he who or who. Cf.: He who pleased everybody died before he was born. He who keeps company with the wolf will learn to howl. Who has never tasted bitter know not what is sweet. Lexical gender may be expressed or not [12]. The latter implies «he + she». Cf.: Men are not to be measured by inches. The customer is always right [13].

Both men and women portray each other in their own inherent stereotypes. Cf.: women are decorative, sex. They represent the triumph of matter over mind, just as men represent the triumph of mind over morals (O. Wilde). When a man acts he is a puppet. When he describes - he is a poet. A woman fondest is to be weighted and found wanting (W. Winchell) [14].

Zeugmatic and paradoxical references look ironical, unexpected, illogical, enigmatic in their battles on the space of nominative (1) and communicative (2) units. Cf.: 1) to make one's coffee and a progress; to make a fuss and a date; to put on a kettle, a dress, a smile and an air; 2) diamonds are girl's best friends; all women like their mothers that is their 
tragedy; it is good girls who keep diaries, the bad look girls never have the time; a nice man is a man of nasty ideas (J. Swift); conscience is a mother-in-law, whose visit never ends; a very much-married man is the herb of the Universe ( $\mathrm{G}$. Mencken).

Conclusions. Gender concept is multidimensional. Alongside with biological features it is known for different charges - mental, anthropocentric, social, cultural, cognitive, linguistic, wordcentric and textocentric. Gender problem works on with its gaps, gains and goals. One should remember this and keep topic fresh and perspective.

\section{КОМУНІКАТИВНА ПОВЕДІНКА: ГЕНДЕРНИЙ АСПЕКТ}

Кобякова І. К., канд. філол.наук, професор,

https://orcid.org/0000-0002-9505-2502

Сумський державний університет

вул. Римського-Корсакова, 2, м. Суми, 40007

E-mail: i.kobyakova@gf.sumdu.edu.ua

Значну роль в різних науках (філософія, історія, лінгвістика, література, мистецтво) відіграють гендерні дослідження, що дозволяють виявляти нові аспекти розвитку мови соціуму, глибще проникати в суть мовних явищ. Об'єкт статті номінується у заголовку роботи (комунікативна поведінка), предметом є рематичне уточнення (гендерний вимір). За результатами останнього виявляються основні атрибути комунікативної поведінки: емоційність та вербальна поведінка. Зазначені величини у роботі осмислюються на матеріалі домінантних складових - лем та алонімів - иляхом димензіонального виміру. Спрацьовують релевантні комплексні методологічні засоби. Використовується лексикографічний дискурс, словникові складові англійської та украӥнської мов. Має місце огляд літератури з релевантних питань. Актуальність роботи, ї̈ зміст, новизна, висновки, перспектива подальшого творчого пошуку подаються в роботі. Стаття присвячена гендерним конструктам англійської мови, лінгвокогнітивним аспектам у фразеологічному просторі, проблемам лінгвістичної гендерології та в котрий раз доведенню того, щчо мова відбиває та фіксує картину світу. Дослідження комунікативної поведінки в гендерному аспекті, стереотипів та асиметрії сприяє виявленню культурних констант, загальноприйнятих оиінок та понять, які стоять за ними та визначення яких служсть допоміжним способом для всеосяжного зображення гендерної мовної картини світу. 3 огляду на вагомість та інтернаціональність зазначеної проблематики, можна сказати, щуо гендерний «вимір» дає можливість інтерпретувати їх з урахуванням гендерної диференціації, виявляти субтексти, щу відбивають символи жіночого досвіду. Нове розуміння текстів дозволяе відійти від літературознавчих, сочіально-політичних та традиційних трактувань, проаналізувати тексти з огляду уявлень про поняття «чоловіче» $i$ «жіноче» в мові та мовленні.

Ключові слова: комунікативна поведінка, чоловік та жінка, гендерний модус, емочійність, інформація, вербальна поведінка, лінгво-когнітивний підхід.

\section{КОММУНИКАТИВНОЕ ПОВЕДЕНИЕ: ГЕНДЕРНЫЙ АСПЕКТ}

Кобякова И.К., канд. филол.наук, профессор,

https://orcid.org/0000-0002-9505-2502

Сумский государственный университет

ул. Римского-Корсакова, 2, г. Сумьl, 40007

E-mail: i.kobyakova@gf.sumdu.edu.ua

Объект исследования (коммуникативное поведение) и его предмет (гендерный аспект) реализуются на материале метазнаков лексикографического дискурса английского и украинского языков. Эмпатируется внимание на грамматической категории рода. Димензиональное измерение осуществляется на материале номинативных и коммуникативных единии гендерной парадигмы в английском и украинском языках. Применяется онтогносеологический прием осмысления композитов составляющих словарные статьи (лемм и аллонимов) гендерной парадигмы. Актуальность темь, новизна, топикальность, валоративность и методологическое обоснование являются неотъемлемыми блоками творческого поиска.

Ключевые слова: коммуникативное поведение, мужчина и женщина, гендерный аспект, эмочиональность, информачия, вербальное поведение, лингвокогнитивный подход.

\section{СПИСОК ВИКОРИСТАНИХ ДЖЕРЕЛ}

1. Кобякова І. К. Лінгво-комунікативні аспекти тендерних конструктів (в англомовних фразеологізмах) / І. К. Кобякова, А. В. Гема // Вісник Сумського державного університету. Серія Філологічні науки. Суми : вид-во СумДУ, 2007. - №2. - С.133-138. - URL: http://tractatus.sumdu.edu.ua/Arhiv/2007-1/25.pdf

2. Горошко О. I. Гендерно маркована лексика / О. І. Горошко, Н. М. Галунова // Ученые записки Таврического национального университета им. В. И. Вернадского. Серія «Філологія». - 2006. - Т. 19. No 2. - C. 99-102. 
3. Burukyna O.A. Gender aspect of translation / O. A. Burukyna // Gender as an intrigue of cognition: Sat. Art. M. : Rudomino, 2000. - P. $99-107$.

4. Horoshko E.I. Gender issues in linguistics / E. I. Horoshko // Introduction to gender studies: in 2 parts: Proc essay [under. Ed. I. Zherebkina]. - Part 1. - Kharkiv : ХЦГЫ; St. Petersburg : Aleteyya, 2001. - P. 508-542.

5. Oppermann K., Weber E. Frauensprache Mannersprache - Die verschiedenen Kommunikationsstile von Mannern und Frauen. - Zurich: Orell Fussli, 1995. - 197 S

6. Linke A. Studienbuch Linguistik / A. Linke, M. Nussnaumer, P. R. Portmann. - Tybingen: Max Niemeyer Verlag, 1996. - $334 \mathrm{p}$

7. Peyer A., Groth R. Sprache und Geschlecht / Studienbibliographie Sprachwissenschaft. - Heidelberg: Groos, 1995. $-215 \mathrm{~S}$

8. Weigel S. Das Weibliche als Metapher 'des Metonymischen: Kritische Uberlegungen zur Konstitution des Weiblichen als Verfahren oder Schreibweise / Frauensprache - Frauenliteratur. Filr und Wider einer Psychoanalyse literarischer Werke / Inge Stephan, Carl Pietzcker (Hrsg.). - Tubingen: Max Niemeyer Verlag, 1986. - S. 56-74.

9. Tannen D. You Just Don`t Understand: Women and Men in Conversation. - Ballantine, 1990. - 204 p.

10. Tannen D. Gender and Discourse. - Oxford University Press, 1996. - 234p.

11. NTC's American Idioms Dictionary by Richard A. Spears. - Jersey City, NJ USA. - 389 p.

12. Bidenko L., Bespalova G. (2017). Implementing Audio-Lingual Method to Teaching Ukrainian as A Foreign Language at The Initial Stage Advanced Education, 2017, Issue 7, S. 23-27. DOI: 10.20535/2410-8286.82711

13. Spender Dale. Man Made Language. - London: Routledge and Kegan Paul, 1980. - 278 p.

14. Lakoff R. Language and Women's Place. - New York: Harper \& Row, 1975. - 168 p.

\section{REFERENCES}

1. Kobyakova, I.K., Gema, A.V. (2007). Lingvocommunicative aspects of gender constructs (in English phraseological units). SSU Visnyk. Series of Philology.№2, 133-138. - URL: http://tractatus.sumdu.edu.ua/Arhiv/2007-1/25.pdf

2. Goroshko, O. I. (2006). Henderno markovana leksika [Gender marked vocabulary]. Uchenyye zapiski Tavricheskogo natsionalnogo universiteta im. V. I. Vernadskogo, 19(2), 99-102. .

3. Burukyna, O. A. (2000). Gender aspect of translation. Gender as an intrigue of cognition: (99-107). Sat. Art. - M.: Rudomino.

4. Horoshko, E.I. (2001). Gender issues in linguistics. [Introduction to gender studies: in 2 parts: Proc. Essay). In I. Zherebkina (Ed.). (pp. 508-542). Kharkiv : Aleteyya.

5. Oppermann, K., Weber, E. (1995). Frauensprache Mannersprache. [Die verschiedenen Kommunikationsstile von Mannern und Frauen]. Zurich: Orell Fussli.

6. Linke, A. (1996). Studienbuch Linguistik. Tybingen: Max Niemeyer Verlag.

7. Peyer, A., Groth, R. (1995). Sprache und Geschlecht [Studienbibliographie Sprachwissenschaft]. Heidelberg : Groos.

8. Weigel, S. (1986). Das Weibliche als Metapher 'des Metonymischen: Kritische Uberlegungen zur Konstitution des Weiblichen als Verfahren oder Schreibweise. Frauensprache - Frauenliteratur. Filr und Wider einer Psychoanalyse literarischer Werke. In Inge Stephan, Carl Pietzcker (Ed.). (pp. 56-74). Tubingen: Max Niemeyer Verlag.

9. Tannen, D. (1990). You Just Don`t Understand: Women and Men in Conversation. Ballantine.

10. Tannen, D. (1996). Gender and Discourse. Oxford University Press. - 234p.

11. NTC's American Idioms Dictionary by Richard A. Spears. - Jersey City, NJ USA. - 389 p.

12. Bidenko, L., Ganna Bespalova, G. (2017). Implementing Audio-Lingual Method to Teaching Ukrainian as A Foreign Language at The Initial Stage Advanced Education. 2017, Issue 7, (pp. 23-27). DOI: 10.20535/24108286.82711 .

13. Spender, D (1980). Man Made Language. - London: Routledge and Kegan Paul.

14. Lakoff, R. (1975). Language and Women's Place. - New York: Harper \& Row.

Received: 18 September, 2018 